\title{
Some Remarks on the Theological Interpretation of the Theory of Evolution
}

\begin{abstract}
This paper deals with the problem of alleged conflict between the theological idea of the creation of man by God and the scientific theories that explain the origin of the human body referring to the process of evolution. It is argued that there is no contradiction between these two domains and that there is no real conflict between the idea of creation and the theory of evolution. At first, the conception of evolution is introduced. Afterwards, the evolutionary creationism is presented as the theological doctrine which claims that God created man, using for this purpose mechanisms of evolution. It is argued that the Biblical account of creation must not be understood literally and that during the lecture of this account one should respect the interpretative principle of St. Augustine concerning metaphorical sense of some Biblical texts. Finally, a "method" of explaining of the emergence of the human body by a direct action of God ("God of the gaps") is criticized.
\end{abstract}

\section{Keywords}

Creation, evolution, creationism, Bible, theory of evolution, evolutionary creationism, God of the gaps, God and evolution.

It seems that science and theology explain the origin of man and the origin of the universe in a completely different way. According to theology both the whole universe and man were created by God; according to science the universe occurred about 13.7 billion years ago as a result of the so called Big Bang, and since then it has been subjected to constant evolution. This evolution has led to the rise of life on the planet Earth, and the subsequent progress of events has led to the emergence of man. These two visions seem inconsistent and this is why some important questions appear about interactions between theological truth about the creation 
and various scientific theories dealing with the evolution of the universe and of life. Is it possible to reconcile the theological idea of the creation of man with contemporary scientific theories? The main goal of this article is to find an answer to that question. The focus will mainly be put on the theory of biological evolution, but some other theories and disciplines of contemporary science which are linked to this problem will be mentioned too, such as relativistic cosmology.

The basic thesis that will be formulated and justified in this paper is as follows: there is no contradiction between the scientific theory of evolution and the theological truth about the creation of the world and of man by God. There's no question that especially today there is a serious need to emphasize that there is no real inconsistency between science and theology. There are some influential groups of philosophers, scientists and even journalists that maintain the myth of conflict between these two domains. According to this myth you can be either intelligent man of science (and then you should not believe in God) or you can believe in God (and then you must not accept what science says). The problem of the origin of man delivers the best example of how this myth works: either man comes from God (and then the theory of evolution is false) or man came into being in the process of evolution (and then he can't come from God).

This myth is not true. There is no real conflict between the truths of faith and the truths of reason. From the point of view of theology it is God who gave a reason to every human being and this is why there's no ground for setting reason against faith ${ }^{1}$. It is exactly what John Paul II said in his encyclical Fides et Ratio: "Faith and reason are like two wings on which the human spirit rises to the contemplation of truth; and God has placed in the human heart a desire to know the truth in a word, to know himself so that, by knowing and loving God, men and women may also come to the fullness of truth about themselves" ${ }^{2}$.

1 Cf. R.J. Berry, God and Evolution: Creation, Evolution and the Bible, Vancouver 2001, Regent College Publishing; K. Klosowski, Pomiędzy ewolucja a kreacja, Warszawa 1994, Wydawnictwo ATK; Ch. Montenat, P. Roux, L. Plateaux, Odkrywanie ewolucji w stworzeniu, Poznań 1993, Wydawnictwo W drodze; R.J. Berry, Bóg i biolog. Wiara a nauki przyrodnicze, Kraków 2005, Wydawnictwo WAM.

2 Jan Paweł II, Encyklika Fides et Ratio. O relacjach między wiara a rozumem, Tarnów 1998, Biblos, p. 5. 


\section{What is evolution?}

In order to be able to discuss the problem in question, one should first of all define precisely the concept of evolution ${ }^{3}$. What is evolution? It is necessary to move back in time about 13.7 billion years to answer that question. According to contemporary cosmology, it is then that the Big bang took place from which our universe started its expansion. At that time life could not exist in any form for at least two reasons. First, because the temperature and the density were too high $\left(\rho=10^{93} \mathrm{~g} / \mathrm{cm}^{3} ; \mathrm{T}=10^{33} \mathrm{~K}\right)$; second, because there were not elements of which all the living organisms are made (first of all, there was no coal). The coal and all of the heavy elements life is built of were produced in the centres of stars much later - several billion years after the Big Bang ${ }^{4}$.

Life could arise only when there was already "prepared material" - i.e. all the elements and simple chemical compounds (both organic and inorganic). Such compounds gave the origin of life on the surface of the young planet Earth $^{5}$. The first living microorganisms were probably the cyanobacteria. They were living in the primitive ocean and producing oxygen, which in turn was necessary for bigger organisms to evolve. Over time organisms began to increasingly develop, and more sophisticated forms of life appeared. After a further 3 billion years life came out of the ocean and it began to colonize the land: first the plants, then the animals. Living organisms - both vegetable and animal - began to increasingly differentiate: some species were lost while others took their place.

These several sentences reveal what, in fact, evolution is: it is a kind of a process of a gradual increase of the complexity of living organisms ${ }^{6}$. Such a "definition" allows to ascertain that evolution itself is not the same as the theory of evolution. It is important to grasp that difference, because it helps

3 Cf. F.J. Ayala, The Big Questions: Evolution, London 2012, Quercus Publishing; E. Mayr, What Evolution is, New York 2001, Basic Books; J.A. Coyne, Why Evolution is True, Oxford 2009, Oxford University Press.

${ }^{4}$ „Even if life were to develop in only one place, a large and old universe would have been required. Billions of years of cosmic evolution are necessary for the appearance of carbonproducing stars, an indispensable element for rise of known forms of life"; J. Życiński, The Anthropic Principle and Theological Interpretation of Nature, "The Review of Metaphysics" 41 (1987), p. 318.

5 The Earth was created about 4,5 billion years ago, that is about 9 billion years after the Big Bang.

6 Cf. M. Heller, J. Życiński, Dylematy ewolucji, Kraków 1990, Polskie Towarzystwo Teologiczne. 
to refute an argument which says that one can reject the theory of evolution since it is "only" a theory and therefore it is not "certain". This argument is invalid because it ignores the aforementioned difference and because it does not take into account what a scientific theory is. Evolution is a process which has been proven by science, and this is why today there's no doubt that life on Earth developed in an evolutionary way. Referring to the word "fact" which is not very precise but intuitively understood one can say that the evolution is fact, i.e. something that is beyond dispute. On the other hand, the theory of evolution is the complex system of notions, definitions, hypotheses and so on - system which explains this particular fact. The theory of evolution - like every other scientific theory - can be discussed and questioned (and this is why there were at least several different theories of evolution), but the fact of evolution itself remains beyond question ${ }^{7}$. A similar state of affairs can be observed e.g. in the theory of gravitation. Gravitation between material objects is a fact, but this fact can be differently explained using the Newtonian theory of gravity, general theory of relativity, or any other physical theory.

When it comes to the theories of evolution, there were several of them. The essential basis of the contemporary theory of evolution was created by Charles Darwin in the middle of XIX century ${ }^{8}$. Darwin pointed to the two mechanisms of evolution - the natural selection and the struggle for existence - but he still did not know genetics, that is, the science of heredity, which appeared not until the XX century. The contemporary theory of evolution (sometimes it is called the synthetic theory of evolution) is the fusion of Darwin's theory and genetics? .

At this point there's no need to explicate "technical details" of this theory. For the purpose of this article it is enough to say that it is a theory which gains the status of a paradigm (i.e. something that nobody questions) in the modern biological sciences. It is worth noting that it's not correct to ask whether this theory is "true". No theory can be "true" (a sentence can be "true" whereas a theory is not a sentence). Instead, a theory can be "empirically confirmed" and this confirmation can be better or worse. It turns out that the theory of

\footnotetext{
Cf. M. Heller, T. Pabjan, Elementy filozofii przyrody, Tarnów 2007, Biblos, p. 180-225.

8 C. Darwin, On the Origin of Species, London 1859, John Murray. Cf. M. Ruse, The Darvinian Revolution, Chicago 1999, The University of Chicago Press.

9 Cf. K.M. Weiss, A.V. Buchanan, Genetics and the Logic of Evolution, New York 2004, John Wiley \& Sons; D.J. Merrell, Evolution and Genetics. The Modern Theory of Evolution, New York 1962, Holt, Rinehart and Winston.
} 
evolution is very well confirmed and this is the main reason for which today no biologist questions it.

\section{Evolutionary creationism}

How should theological interpretation of the theory of evolution look like? Or, in another words, how can one understand theological truths about the creation of the world and of man in the light of the theory of evolution? There are several possibilities. The majority of catholic theologians advocate the so called evolutionary creationism, which claims that God creates the world and creates man, using for this purpose mechanisms of evolution. It is the doctrine which in a sense allows to coordinate the theories of modern science and the theological truth about creation. According to this doctrine, God creates the laws of nature (the laws of physics, chemistry, biology etc.), and these laws are the cause of the evolution of the universe and of life itself ${ }^{10}$. In other words: God does not create everything - every single species of plants and animals - in finished form, but calls to existence individual organisms gradually. He just uses the laws of physics, chemistry and biology, which cause the evolution of life.

Of course, one should not forget that the biological evolution concerns exclusively the biological "part" of man, i.e. his body, which is built up of the same atoms and elements as the whole material universe. However, from the theological point of view, man is not only the body but the soul as well. The soul is not material, not biological, and therefore it is not subjected to evolution. To be able to put together a theological truth about the creation of man by God and the theory of biological evolution one has to accept that at some stage of the evolutionary process, which concerned only and exclusively the material body, God created the soul. It was then that what previously was

${ }^{10}$ Some new approaches to the problem of God's presence in the evolving nature and particularly in the laws of nature are discussed by J. Życiński in his books and articles: God and Evolution. Fundamental Questions of Christian Evolutionism, Washington 2006, The Catholic University of America Press (Bóg i ewolucja. Podstawowe pytania ewolucjonizmu chrześcijańskiego, Lublin 2002, Towarzystwo Naukowe KUL); Wszechświat emergentny. Bóg w ewolucji przyrody, Lublin 2009, Wydawnictwo Naukowe KUL; Bóg i stworzenie. Zarys teorii ewolucji, Lublin 2011, Gaudium; Beyond Necessity and Design: God's Immanence in the Process of Evolution, „CTNS Bulletin“ 22 (2002), p. 3-10; Christian Theism and Cosmic Evolution, „Revista Portuguesa de Filosofia” 61 (2005), p. 211-233. 


\section{The Person and the Challenges \\ 204 \\ Volume 3 (2013) Number 1}

only animal body, has become a man. John Paul II spoke in this context about some discontinuity or ontological "jump"11: before this particular moment there was only the matter, only the biological body, and a while later - the matter and the soul, which together constitute the "substance" of man. Of course, today nobody can precisely indicate in which moment of evolutionary process this "point of hominisation" took place. Probably this happened when our biological predecessors became self-conscious and became able to make moral judgments, that is, to distinguish between good and evil.

From the Christian perspective, man is composed of the material body and of the immaterial soul: the soul comes directly from God, whereas the body comes from God too, but indirectly - because it appears as a result of the evolution which is controlled by the laws of nature, and these laws are the manifestation of God's rationality in the world of nature. There is a popular propaganda slogan which says that the theory of evolution proved "man comes from the ape". For many Christians this idea seems completely contrary to their faith. The theologically correct interpretation of this expression is the following: man does not come from the ape but from God; however, since man is body and soul, the soul comes from God directly, and the body - indirectly. The body of man, just as the body of ape, tiger, fish, etc., comes from God too, however it was not formed directly out of clay (as The Book of Genesis proclaims ${ }^{12}$ ), but it emerged as a result of the evolutionary processes which are guided by the laws of nature - laws that have their source in $\operatorname{God}^{13}$.

The primary consequence of evolutionary creationism is that there's no contradiction between faith and reason, that is, between theological doctrine about creation and scientific theory of evolution. Of course, evolutionary creationism

11 John Paul II spoke of "an ontological jump" during his discourse to the Pontifical Academy of the Sciences on August 22, 1996. Cf. J. Życiński, Evolution and Christian Thought in Dialog according to the Teaching of John Paul II, "Logos. A Journal of Catholic Thought and Culture" 9 (2006), p. 13-27.

12 "Then the Lord God formed a man from the dust of the ground and breathed into his nostrils the breath of life, and the man became a living being"; Genesis 2,7.

13 „In the explanatory framework of Christian theism, God understood as an evolutionary attractor shares with all creatures their own openness to a future that is not fully determined. In this framework, one recognizes the importance of physical necessity which, as instantiated in the laws of physics, turns out to be a form of God's immanence in nature. Cosmic order, that inspired so many physicists in expressing their astonishment with the rational structure of physical processes, discloses divinity hidden in the evolving nature"; J. Życiński, The Rationality Field and the Laws of Nature, in: Wyzwania racjonalności, S. Wszołek, R. Janusz (eds.), Kraków 2006, WAM, p. 96. 
is not confined solely and exclusively to the issue of human evolution, but it concerns the creation of the whole universe, which is also subject to constant evolution. In this perspective, the evolution of life is only one of the fibres or stages of the global, cosmic evolution of the universe $\mathrm{e}^{14}$. God creates the universe and controls its constant development using for this purpose the laws of nature which are the cause of the continual evolution of matter.

\section{Can the Biblical narrative of creation be understood literally?}

There are different interpretations of creationism. The simplest one is as follows: God created the whole world together with all the plants, animals and man himself exactly in such a way as it is presented in the first two chapters of the Genesis. In another words, this interpretation of creationism claims that the Biblical narrative of the creation of the world and of man should be understood literally. This standpoint is known as naïve creationism, because it advocates some naïve understanding of the Bible. This idea was particularly intensively promoted in the USA in the beginning of the XX century by some religious fundamentalists who coined for it the name "scientific creationism" (known also as "creation science"). Such a term is nothing but a publicity stunt which is misleading and confusing because this position has nothing in common with science ${ }^{15}$.

At present Biblical scholars have no doubt that the story of the creation from the Book of Genesis is neither scientific nor historical. It is a poem, that is, a form of poetry, which has a theological, but not a scientific, message. What the inspired author wanted to express in this fragment of the Bible was the theological truth that everything that exists comes from God and is created by God, but his story does not say anything about the "technical details" of creation. The Biblical poem does not concern scientific facts but theological truths, and this is why it cannot be treated as scientific account of creation. The Bible is not a handbook of biology, physics or cosmology and therefore one cannot try to find out within the Biblical books something that is not there - i.e., information on biology, physics and cosmology. It is obvious

${ }^{14}$ Cf. M. Heller, Filozofia przypadku. Kosmiczna fuga z preludium i koda, Kraków 2011, Copernicus Center Press, chapter 14 (p. 163-173).

${ }^{15}$ Cf. ibid., chapter 10 (pp. 133-140); J. Życiński, Bóg i ewolucja, op. cit., pp. 29-32. 
that to find such information, one should look for it not in the Bible, but in the domain of the scientific disciplines that deal with the "technical details" of the emergence of the universe and of the life. As it was previously said, such a discipline that deals with the universe is cosmology, whereas the scientific theory concerning the emergence of the life is the theory of evolution ${ }^{16}$.

Of course, if one accepts a literal understanding of the Biblical story of the creation, one has to regard scientific theories as false. This is why such an attitude actually leads to conflict between faith and reason, because one cannot at the same time accept the literal meaning of the Biblical narrative of the creation and accept what contemporary science says about the beginning of the universe and the origin of life. It's not surprising that the adherents of naïve creationism fight against the theory of evolution (and against other theories of contemporary science) and treat it as a threat to the Christian faith. Such an approach excludes the possibility of reconciling faith and reason and, in consequence, it is responsible for a rejection of the reason: if there's no way to reconcile the theory of evolution with the literal wording of the Bible, one has to acknowledge that this theory is false.

One reason for which naïve creationism is an improper idea was mentioned above: because a literal treatment of the Biblical narrative of creation is a mistake and the present-day Biblical scholars are agreed about that. But there are many other such reasons and for the purpose of this paper it is worth referring to two of them.

\section{Interpretative principle of St. Augustine}

In the beginning of the $\mathrm{V}$ century St. Augustine of Hippo formulated an interpretative principle regarding the reading of the Bible ${ }^{17}$. This principle says that if anywhere a contradiction between the literal understanding of the Biblical account and "a well established truth of reason" appears, one should look for the metaphorical sense of this account. What does it mean "a well

${ }^{16}$ Cf. Początek świata - Biblia a nauka (esp. J. Homerski, Pieśń o stworzeniu świata; S. Grzybek, Teologia kapłańskiego opisu stworzenia świata; J. Chmiel, Hermeneutyczne przesłanki biblijnej interpretacji opisów stworzenia; M. Bednarz, Urząd Nauczycielski Kościoła odrzuca fundamentalistyczna interpretację Pisma Świętego), M. Heller, M. Drożdż (eds.), Tarnów 1998, Biblos.

${ }^{17}$ St. Augustine formulated this principle in the first book of his Literal Commentary on Genesis, esp. in chapters 18-21. 
established truth of reason"? Today it is just science that can reasonably establish all the important "truths" regarding the world of nature ${ }^{18}$. There's no doubt that the evolution of life, and of the whole universe, are such truths. If the theory of evolution says that the human body is a result of a long process of biological evolution (and the relativistic cosmology says that the current universe came into being thanks to the cosmic evolution of matter), and if this scientific truth is inconsistent with the literal meaning of the Biblical narrative of creation, one must search for the metaphorical sense of the first two chapters of Genesis. Previously it was said how such a sense should be understood: all that exists (the whole universe and life in it) comes from God. Here is the truth that is the most important for the inspired author, whereas all the "technical details" are not important for him".

Why is it necessary to use this method of interpretation of the Bible? St. Augustine says that if a Christian does not respect the principle in question, he makes the Christian faith ridiculous in the eyes of pagans. It's not difficult to notice that this remark is exceptionally timely today: if a Christian knows a well established truth of science (e.g. that life is an effect of an evolutionary process) and if he rejects this truth and chooses a literal meaning of the account of man's creation, then he makes his faith look ridiculous in the eyes of present-day pagans (i.e. atheists) ${ }^{20}$. One more remark could be added to this argument of St. Augustine: such a faith resembles very much a fundamentalist faith, and a Christian should be aware of this risk ${ }^{21}$. Besides, there's no doubt that imagining and representing God as a man (old one, most often with a long beard) who takesa clay in his hands and shapes eyes, ears, nose, etc. - is not something that today could convince anybody. Such a representation could rather be used to make fun of the Christian faith. In the past, the Catholics have repeatedly made a mistake when they have insisted on a literal understanding of the Bible questioning scientific theories. The Galileo affair is a good example here ${ }^{22}$. Since such mistakes have always had distressing consequences, one must avoid repeating them.

${ }^{18}$ Cf. E. McMullin, Ewolucja i stworzenie, Kraków 1993, OBI, p. 3.

${ }^{19}$ Cf. T. Brzegowy, Kosmologia (kosmogonia) biblijna, in: Duch i Oblubienica mówią: „Przyjdź”, W. Chrostowski (ed.), Warszawa 2001, Vocatio, p. 70-74.

${ }^{20}$ Cf. M. Heller, Filozofia przypadku, op. cit., p. 153-154.

${ }^{21}$ Cf. J. Życiński, Bóg i ewolucja, op. cit., p. 32-39.

${ }^{22}$ Cf. Sprawa Galileusza, J. Życiński (ed.), Kraków 1991, Znak. 


$208 \quad \begin{aligned} & \text { The Person and the Challenges } \\ & \text { Volume } 3 \text { (2013) Number } 1\end{aligned}$

\section{God of the gaps}

The interpretative principle of St. Augustine is an important argument against naïve creationism. Another one comes from a methodological rule that is known as methodological naturalism ${ }^{23}$. According to this rule, behavior of physical entities should be explained by behavior of other physical entities (an analogous rule could be framed for non-physical or supernatural entities that theology talks about). If the human body is a part of the physical world, then its origin needs to be explained by the laws that govern the physical world, i.e. the laws of physics, chemistry, biology, and so on. As far as the soul is concerned, it is not physical and therefore God is needed to explain its beginning. But a serious methodological error occurs when one explains the emergence of the human body by a direct action of God. The history of science (and of theology) shows that this "method" of explaining the physical world was often applied in the past, and it always turned out to be to the detriment of theology and of faith. At present this way of explaining is ironically called "the method of filling the gaps of scientific knowledge by means of God" (in short: "God of the gaps") ${ }^{24}$. This method works as follows: if there is a problem with explaining the world of nature, and one cannot solve this problem by means of scientific methods - it appears to be a gap in scientific knowledge - one says: it is God who makes this happen. In other words, one fills the gap of scientific knowledge with God. This method of explaining of the world of nature is invalid for at least two reasons ${ }^{25}$. The theological error of this reasoning is that, in this case, one tacitly assumes that God was not far-sighted enough to create the world that does not need corrections and extraordinary interventions. In this view, God is not a very clever clockmaker having built a defective clock which he must repeatedly repair, adjust and reset. There is no doubt that a much better clockmaker is the one who makes a clock which needs no repairs, adjustments nor resetting. The second error of the aforementioned reasoning ("God of the gaps") appears over time when science itself fills the gaps in the scientific knowledge. Of course, the hypothesis of God becomes unnecessary then, and the whole reasoning turns

${ }^{23}$ Cf. Naturalism: A Critical Analysis, W.L. Craig, J.P. Moreland (eds.), London 2000, Routledge; Nature of Nature: Examining the Role of Naturalism in Science, B.L. Gordon, W.A. Dembski (red.), Delaware 2011, ISI Books.

${ }^{24}$ Cf. E. McMullin, Ewolucja i stworzenie, op. cit., p. 53-73.

${ }^{25}$ Cf. M. Heller, Ostateczne wyjaśnienia wszechświata, Kraków 2008, Universitas, p. 210-212. 
against faith in God. Even more, such reasoning becomes an argument for atheism. When somebody is told that God formed the human body out of clay, and later he learns about the theory of evolution (which says that the human body emerged as a result of the evolutionary processes), then it's not surprising that he can state that there's no God - because science explained what was previously explained by the actions of God. In such a way a reasoning that was supposed to be an argument for faith in God, becomes an argument against such faith. The laudable intentions are not enough to actually defend the faith. The result is in this case exactly the opposite ${ }^{26}$.

\section{Concluding remarks}

It's time to summarize the analyses that were made in this paper. There's no reason to oppose the theological truth about the creation of man by God and the scientific theory that explains the origin of life, i.e. the theory of evolution. There's no contradiction between these two conceptions. The evolutionary creationism is a present-day theological doctrine which says that God is the creator of the world and of man and the giver of life, but in the process of creation He uses the laws of nature, and these laws are the cause of the evolution of life.

At least since the time of St. Augustine and St. Thomas Aquinas theologians know the idea of continuous creation (creatio continua) according to which creation was not a single act of God in the past or in the beginning of the universe, but it is a continuous, creative action of God who sustains the whole world in existence. If God would withdraw his creative act, everything would cease to exist. It's interesting that St. Augustine formulated this theory in the beginning of the V century, and St. Thomas returned to it in the XIII century - despite the fact that none of them knew anything about the theory of evolution nor about evolutionary creationism. And it is precisely these

\footnotetext{
26 "In looking for such explanation we should exclude a reference to the God of the gaps which becomes a useless hypothesis after new scientific discoveries have been made [...]. God reveals His presence not in the gaps of our knowledge about Nature, but in the laws of nature and in the cosmic harmony constituted by these laws. [...] When cosmological disclosure of the laws of nature replaces our psychological biases, the immanent God is discovered rather as the God of the whole than a god of holes in our knowledge"; J. Życiński, The Rationality Field and the Laws of Nature, op. cit., p. 93-94.
} 
$210 \quad \begin{aligned} & \text { The Person and the Challenges } \\ & \text { Volume } 3 \text { (2013) Number } 1\end{aligned}$

theories that allow for better understanding of the idea of continuous creation: God constantly executes his creative act because He uses the laws of nature that control the process of evolution of the universe and of life in it.

It is easy to prove that modern man has a scientific worldview: there's no doubt that it is just science that gives us some basic information about the world. This is an important reason for which the truths of faith (for example, the truth about the creation of man) have to take into account such a worldview. There was a time when the so called theory of double truth was popular. According to this theory, the same thesis can be true in philosophy (or science) but false in theology, and vice versa. But such a theory is false. A man who believes in God is a psychophysical unity and lives in one world that is not divided into the sphere of religion and the sphere of science, and this is why he must have a coherent worldview in which the truths of faith are not in conflict with the truths of science. The problem of the origin of man is a good example that confirms this truth.

\section{Bibliography}

Ayala F.J., The Big Questions: Evolution, London 2012, Quercus Publishing.

Berry R.J., Bóg i biolog. Wiara a nauki przyrodnicze, Kraków 2005, Wydawnictwo WAM. Berry R.J., God and Evolution: Creation, Evolution and the Bible, Vancouver 2001, Regent College Publishing.

Brzegowy T., Kosmologia (kosmogonia) biblijna, in: Duch i Oblubienica mówiq: „Przyjdź”, W. Chrostowski (ed.), Warszawa 2001, Vocatio, p. 70-74.

Coyne J.A., Why Evolution is True, Oxford 2009, Oxford University Press.

Craig W.L., Moreland J.P., (eds.), Naturalism: A Critical Analysis, London 2000, Routledge.

Darvin C., On the Origin of Species, London 1859, John Murray.

Gordon B.L., Dembski W.A. (eds.), Nature of Nature: Examining the Role of Naturalism in Science, Delaware 2011, ISI Books.

Heller M, Drożdż M. (eds.), Początek świata - Biblia a nauka, Tarnów 1998, Biblos.

Heller M., Filozofia przypadku. Kosmiczna fuga z preludium i koda, Kraków 2011, Copernicus Center Press.

Heller M., Ostateczne wyjaśnienia wszechświata, Kraków 2008, Universitas.

Heller M., Pabjan T., Elementy filozofii przyrody, Tarnów 2007, Biblos.

Heller M., Życiński J., Dylematy ewolucji, Kraków 1990, Polskie Towarzystwo Teologiczne.

Jan Paweł II, Encyklika Fides et Ratio. O relacjach między wiara a rozumem, Tarnów 1998, Biblos. 
Klosowski K., Pomiędzy ewolucją a kreacja, Warszawa 1994, Wydawnictwo ATK.

Mayr E., What Evolution is, New York 2001, Basic Books.

McMullin E., Ewolucja i stworzenie, Kraków 1993, OBI.

Merrell D.J., Evolution and Genetics. The Modern Theory of Evolution, New York 1962, Holt, Rinehart and Winston.

Montenat Ch., Roux P., Plateaux L., Odkrywanie ewolucji w stworzeniu, Poznań 1993, Wydawnictwo W drodze.

Ruse M., The Darvinian Revolution, Chicago 1999, The University of Chicago Press.

Weiss K.M, Buchanan A.V., Genetics and the Logic of Evolution, New York 2004, John Wiley \& Sons.

Życiński J. (ed.), Sprawa Galileusza, Kraków 1991, Znak.

Życiński J., Beyond Necessity and Design: God's Immanence in the Process of Evolution, „CTNS Bulletin“ 22 (2002), p. 3-10.

Życiński J., Christian Theism and Cosmic Evolution, „Revista Portuguesa de Filosofia” 61 (2005), p. 211-233.

Życiński J., Evolution and Christian Thought in Dialog according to the Teaching of John Paul II, "Logos. A Journal of Catholic Thought and Culture" 9 (2006), p. 13-27.

Życiński J., The Rationality Field and the Laws of Nature, in: Wyzwania racjonalności, S. Wszołek, R. Janusz (eds.), Kraków 2006, WAM, p. 87-101.

Życiński J., The Anthropic Principle and Theological Interpretation of Nature, "The Review of Metaphysics" 41 (1987), p. 317-333.

Życiński J., Bóg i stworzenie. Zarys teorii ewolucji, Lublin 2011, Gaudium.

Życiński J., God and Evolution. Fundamental Questions of Christian Evolutionism, Washington 2006, The Catholic University of America Press, (Bóg i ewolucja. Podstawowe pytania ewolucjonizmu chrześcijańskiego, Lublin 2002, Towarzystwo Naukowe KUL).

Życiński J., Wszechświat emergentny. Bóg wewolucji przyrody, Lublin 2009, Wydawnictwo Naukowe KUL. 